\title{
Gas Valorization in the Republic of Congo: Production of Electricity from National Gas Reserves
}

\author{
Prince Valdano Itoua ${ }^{1 *}$, Durell Esperance Ndinga Manguet ${ }^{2}$ \\ ${ }^{1}$ School of Economics and Management, North China Electric Power University, Beijing, China \\ ${ }^{2}$ School of Management and Economics, Hubei University of Technology, Wuhan, China \\ Email: *princeitoua@yahoo.fr, *princevaldano@163.com
}

How to cite this paper: Itoua, P.V. and Ndinga Manguet, D.E. (2021) Gas Valorization in the Republic of Congo: Production of Electricity from National Gas Reserves. Natural Resources, 12, 164-180. https://doi.org/10.4236/nr.2021.125012

Received: April 21, 2021

Accepted: May 28, 2021

Published: May 31, 2021

Copyright $\odot 2021$ by author(s) and Scientific Research Publishing Inc. This work is licensed under the Creative Commons Attribution International License (CC BY 4.0).

http://creativecommons.org/licenses/by/4.0/

\section{(c) (i) Open Access}

\begin{abstract}
The environmental impact of greenhouse gases based on natural gas flaring influences the rate of gas recovery around the world. In the Republic of Congo, the natural gas reserve in 2019 is estimated at 90 billion cubic meters (BCM). In this study, from the Congolese gas reserve we used five gas turbines with a capacity of $150 \mathrm{MW}$ each; these five turbines consume 1.69 billion cubic meters (BCM)/year for the power of $273.750 \mathrm{MW}$ and consumption of 6.57 billion kilowatt-hours. The results of this study revealed that an investment capital of 192,305,137 euros was required with a net profit of 9,581,250 euros at an annual rate of return of $4.98 \%$ with an investment payback period of approximately 20 years. This will allow the Congolese government to accomplish its policy of valuing gas and developing the country; the electricity produced by the National Petroleum Company of Congo (SNPC) will be sold to the Electrical Energy of Congo $\left(E^{2} C\right)$ at 0.06 euro/kWh.
\end{abstract}

\section{Keywords}

Gas Valorization, Gas Turbines, Wire Gas Technology (GTW), Electrical Energy of Congo $\left(\mathrm{E}^{2} \mathrm{C}\right)$, National Petroleum Company of Congo (SNPC)

\section{Introduction}

Despite the difficulties encountered more precisely, the lack of documents dealing with the impact of the three variables (production, utilization and flaring of gas) on economic growth at the national and international.

According to [1], the year 2019 witnessed about; we have taken stock of the 
natural gas reserves of eight (8) African countries represented in Figure 1, of which the Republic of Congo is moving, with a reserve of about 90 billion cubic meters $(\mathrm{BCM})\left(53^{\text {rd }}\right.$ in the world and $8^{\text {th }}$ in Africa). Nigéria is the top on the list with 5475 milliards (BCM); Algérie 4504 milliards (BCM); Mozambique 2832 milliards (BCM); Égypte 2186 milliards (BCM); Libye 1505 milliards (BCM); Angola 308 milliards (BCM); Cameroun 135 milliards (BCM). However, it should be noted that gas is less valued in the Republic of Congo.

The Republic of Congo is an oil-producing country and produces natural gas but in small quantities due to the high flaring rate. Decree 2007-294 prohibits the systematic combustion of natural gas in all oil and gas installations, except with special authorization from the Ministry of Hydrocarbons, under the 2015 Paris Agreement (COP21), to which the Republic of Congo is committed to limit greenhouse gas emissions, a large part of which is caused by the flaring of natural gas. Indeed, in May 2016, the Republic of Congo in partnership with the World Bank set up a program to reduce gas flaring and upgrading; On October 12, 2016, the Ministry of Hydrocarbons established a new hydrocarbons code $\mathrm{n}^{\circ}$ 2016-28, Section 2-Flaring of associated gases: Article 136, flaring of associated gases, except for flaring carried out within the framework of tests, safety or any other occasional oil work according to the rules of the art generally accepted in the international hydrocarbon industry, is prohibited without special and prior authorization from the minister in charge of hydrocarbons issued under the regulations in force. Subsequently, article 137, the procedures for filing and processing requests as well as the procedures for granting special and prior flaring authorizations are set by decree in the Council of Ministers, requests for special and prior authorization from flaring includes, in particular, the evaluation of alternatives for use or recovery, information on the quality and quantity of gas concerned as well as the required flaring time [2].

The main goal of this study is to make our contribution to the national gas valuation policy and environmental protection, the national petroleum company

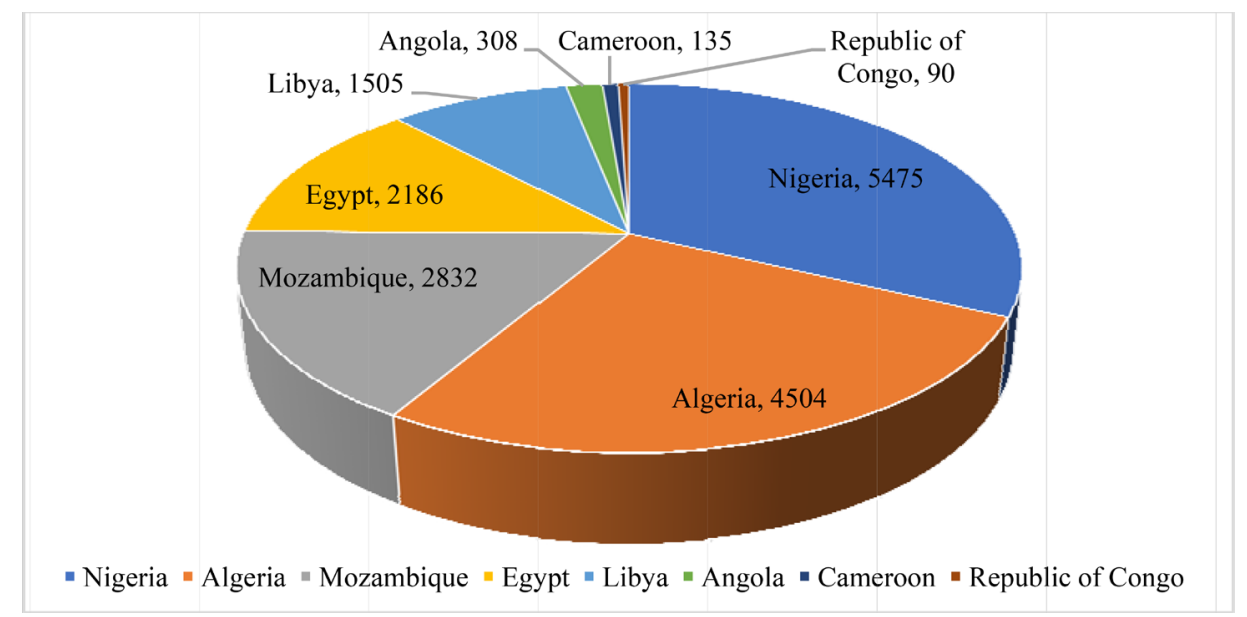

Source: Data from [1].

Figure 1. Top eight natural gas reserves African countries. 
of the Congo (SNPC) from national natural gas reserves using Wire Gas Technology (GTW) to produce electricity which will be sold to Electrical Energy of Congo $\left(\mathrm{E}^{2} \mathrm{C}\right)$ at 0.06 euro/kWh.

Indeed, this study was carried out as follows: Section 1 data collection, section 2 presentation of the national petroleum company of the Congo (SNPC) and the Electrical Energy of Congo $\left(\mathrm{E}^{2} \mathrm{C}\right)$; section 3 global trend of thermoelectricity generation compared with the Republic of Congo; section 4 evolution and prediction of the population; section 5 electricity production and demand estimation; section 6 application of Gas to Wire Technology (GTW) from Congo natural gas reserves.

\section{Literature Review}

One of the methods suitable for systemic reduction and elimination of gas flares is the generation of electricity with the power cycle. The basic principle of the power cycle requires the use of a gas turbine (GT) to generate electricity. Gas turbines are increasingly used for the production of electricity, especially when large quantities of natural gas are abundant [3] [4]. Turbines generate high powers with high efficiencies and low emissions and can also be used in simple cycle mode for the production of mechanical energy and electricity at baseload in the oil and gas sector where natural gas and the process gases were used as fuel, and their maintenance costs are much lower than those of liquid fuels.

According to Meetham [5], the advantages of the gas turbine are: the ability to burn various qualities of gas than other alternative engines, lower maintenance cost with few moving parts, less vibration and noise. The literature [6] and [7] has emphasized that the production of electricity from natural gas has the advantages of high energy efficiency, energy-saving, and environmental protection, as well as flexible adjustment. The development of electricity production from natural gas is conducive to the achievement of strategic energy conservation and emission reduction objectives while improving the operational safety of the network. Therefore, it is emphasized that the production of electricity from natural gas will play an important role in the low carbon transition process of the Chinese energy industry. The literature [8] has pointed out that the large-scale use of electricity generation from natural gas is an important means of building green, low-carbon cities and other environmental protection work in mega-cities. The literature [9] [10] has emphasized that, as Chinese environmental protection standards are gradually brought into line with those of developed countries, natural gas as clean energy will be vigorously promoted and applied. The literature [11] [12] compared the effects of the production of energy from natural gas and coal on the protection of the environment and underlined that the production of energy with natural gas instead of the production with coal can assist the energy sector in achieving its strategic objective of energy conservation and emission reduction.

Therefore, China's electricity sector presented a strategic plan for the mod- 
erate development of natural gas electricity generation during the "twelfth five-year plan", which is expected to reach 30,000 MW and 40,000 MW respectively large-scale production capacity. According to the resource profile published by the Ministry of Land and Resources, China's proven natural gas reserves in 2011 were $3.8 \times 1013 \mathrm{~m}^{3}$ and gas producers use natural gas to generate electricity, which allows them to obtain profits on the sale of natural gas and the production of energy from natural gas. In China, the installed capacity for generating electricity from natural gas will represent $4 \%$ of the total installed power of electricity. Consequently, the literature [13] [14] has underlined that during the periods "Twelfth five-year plan" and "Thirteenth five-year plan", the sector of energy production from natural gas will offer good prospects for development. However, the literature [8] [15] [16] [17] [18] have pointed out that the natural gas industry in China still poses certain problems. First, China does not have standardized regulations or standards for natural gas power projects, which prevents power projects from achieving energy conservation and economic goals expected. Second, the cost of generating electricity is high, which results in unprofitable projects for producing electricity from natural gas. Third, connecting to the decentralized natural gas production network is difficult and expensive. Fourth, there is a wide gap between the level of manufacturing of natural gas power generation equipment in China and the advanced level of the world: the basic technology depends on imports and the development of the electricity generation sector in China. Natural gas base depends on the population. Fifth, China's natural gas reserves are not very rich and the distribution of natural gas resources is uneven, there are huge differences between East and West and the long-distance transport of natural gas resources. Natural gas is difficult. In recent years, domestic and foreign specialists have done a lot of research on the prices of natural gas and electricity in China and are very worried. The documents [19] [20] indicated the main means allowing the gas power stations to take part in the invitation to tender and to the connection to the network through research: first, the part not related to the cost of the fuel of the power stations with gas participated in the competition. Thus, fuel costs are transferred to electricity users via the electricity market or subsidized by the government, the second being to increase the price of the capacity of gas-fired power plants in the price of electricity to two units and to include the cost of fuel for power plants and construction of infrastructure. Appropriately reflected in its cost of capacity, thereby reducing the cost of fuel for power plants and increasing the price competitiveness of natural gas electricity generation. Some specialists have summarized the various measures taken by governments to encourage the development of gas-fired plants. The literature [21] has pointed out that American gas-fired power plants can participate in short-term and long-term contracts and offer electricity offers to help gas-fired power plants avoid risks and improve their competitiveness, while the UK electricity market makes full use of developed financial markets and financial futures products help natural gas plants avoid risks between the natural gas 
market and the electricity market driven by an abundant supply of natural gas and strict environmental protection policies, the US natural gas distributed energy sector has grown rapidly. The United States has advocated the development of small distributed gas cogeneration technologies since 1978. Between 1980 and 1995, the total installed capacity of gas distributed energy systems increased from $12 \mathrm{GW}$ to $45 \mathrm{GW}$. In 2001, the United States built a total of 978 natural gas distributed energy projects for public and public buildings with a total installed capacity of approximately 5 million $\mathrm{kW}$; Over 50 million $\mathrm{kW}$. In 2003 , the total installed capacity of energy distributed by natural gas was 56 million $\mathrm{kW}$ or $7 \%$ of total installed power in the United States and $9 \%$ of total production in the United States. According to the relevant planning of the United States Department of Energy, by 2020, the combined capacity of combined heat and power generators in the United States will represent $29 \%$ of the total installed power for generating electricity in the country, whose natural gas distributed energy systems will occupy a more important place; Power plants already account for $18 \%$ of total electricity production in Europe and the estimated supply has reduced carbon dioxide emissions by around 150 million tons. At present, the energy production capacity of gas distributed energy projects implemented in Europe represents around 10\% of total electricity production in Europe; Denmark has promoted distributed energy technology since the 1980s and the share of distributed energy sources in the overall energy system the installed capacity of Danish gas-fired cogeneration reached 5.69 GW at the end of 2006. From the UK, distributed energy projects have grown rapidly. According to the British Energy Statistical Yearbook 2008, the total installed capacity of the British natural gas-fired energy system reached $5474 \mathrm{MW}$ in 2007, and total electricity production represented $7 \%$ of total British electricity production this year. In the UK, natural gas distributed energy projects are mainly distributed in restaurants, shopping malls, hospitals, universities, airports, and public and commercial buildings. Also, some experts and academics have conducted research and designed perspectives for promoting and applying the production of electricity from natural gas, electricity pricing systems, etc. for specific regions and projects in China. Reference [22] [23] [24] [25]conducted an in-depth analysis of the state of natural gas electricity generation in Shenzhen, eastern China, in the Pearl River Delta and in the second project of the West-East gas pipeline, and summarized the results of these studies [26]. The characteristics of natural gas energy production projects summarize the classification methods for natural gas energy production projects and propose methods of classification approval. These studies show that projects for the production of electricity from natural gas have been tested in many regions of China and that related theoretical and practical research has also laid the foundations for a certain development which has enabled to vigorously promote the development of energy production from natural gas during the period of the "twelfth five-year plan".

In recent years, while large traditional gas-fired plants have been constantly 
promoted and applied, technology for decentralized natural gas production has also started to attract people's attention [27] [28] [29] [30] introduced the definition and the characteristics of the decentralized production technology commonly used internationally. The connection to the distributed electricity production network will have an impact on users, network companies and society, the impacts of the different stakeholders not being the same, it is necessary to research the point of view from different stakeholders. The literature [31] [32] has analyzed the economic benefits of distributed power generation projects from a user perspective. According to analysis and research, in the current political context in China, the economic aspects of distributed energy production projects are not significant. This also limits to some extent the development of the decentralized energy production sector.

Current technology (GTW) is used all over the world for the valorization of gas, among others, we mention China and Nigeria. In Nigeria (power plant of 50 turbines), the estimated capital investment is high, the rate of return on investment is high. With a gas volume of $16,972,500,000 \mathrm{~m}^{3}$ per year and generates 2,737,500 MW of electricity per day [33]. Therefore, GTW is a tool for gas development and economic development.

\section{Data Collection}

The data for this study were collected from various reliable sources, such as official documents from the Ministry of Hydrocarbons, Ministry of Energy and Hydraulic, World Bank (GGFR) May 2016.

Firstly, at the Ministry of Hydrocarbons, after a working session within this ministry, we obtained the following information: 2007 decree which prohibited systematic flaring in the country; Hydrocarbons Law Code 2016-28, Chapter 2 Concerning associated gas (Article 1-Recovery of associated gas, Section 2-Flaring of associated gas) [2].

Secondly, at the Ministry of Energy and Hydraulics: information on installed and active energy in Congo; Decree: 2017-248 of July 17, 2017, setting the conditions for the exercise of independent electricity production; Article 2: Independent electricity production is all the operators relating to the establishment and operation for commercial purposes of private electricity production systems by legal persons governed by public or private law. The energy produced by the independent producer is sold to the operator of the national electricity distribution network or directly to legal entities governed by public or private law.

Finally, the report the World Bank (GGFR) Reduction of flaring and recovery of gas in the Republic of Congo serves as a support for the rate of electricity sold to Electrical Energy of Congo $\left(\mathrm{E}^{2} \mathrm{C}\right)$.

Regarding our study, we chose the option in which the energy produced by the independent producer is sold to the manager of the national electricity distribution network (Electrical Energy of Congo under the acronym $\mathrm{E}^{2} \mathrm{C}$ ), at approximately 0.06 euro/KW [34]. 


\section{Presentation of the National Petroleum Company of Congo (SNPC) and the Electrical Energy of Congo $\left(\mathrm{E}^{2} \mathrm{C}\right)$}

The National Petroleum Company of Congo (SNPC) is a public industrial and commercial establishment with a board of directors, entirely owned by the State and placed under the supervision of the Ministry of Hydrocarbons, established strategies to support the government in its flaring reduction and gas recovery policy. Created by law n ${ }^{\circ} 1-98$ of April 23, 1998, Present in all sectors of activity of the oil chain (from Upstream to Downstream), it undertakes exploration activities directly or through its subsidiaries, production, processing, transport, and marketing of liquid or gaseous hydrocarbons throughout the Congolese territory and abroad through its subsidiaries: National Research and Production Company (SONAREP), Petroleum Drilling Company (SFP), Integrated Logistics Services (ILOGS), Congolese Refining (CORAF), SNPC-Distribution (SNPC-D).

Electrical Energy of Congo $\left(\mathrm{E}^{2} \mathrm{C}\right)$ placed under the supervision of the Ministry of Energy and Hydraulics, has for mission to guarantee the quality and universal access to the energy heritage of Congo, among its main missions are also production, transport, distribution, and marketing of electrical energy throughout the entire national territory.

\section{Global Trend of Thermoelectricity Generation Compared with the Republic of Congo: Electricity Production from Natural Gas}

Natural gas, due to its clean-burning nature, has become a very popular fuel for power generation. In the 1970s and 1980s, the choices for most power generators were large coal-fired or nuclear-powered plants. However, due to economic, environmental, and technological changes, natural gas has become the fuel of choice for new power plants built since the 1990s. The Energy Information Administration (EIA) estimates that between 2009 and 2015, 96.65 gigawatts of new electricity capacity will be added in the United States, of which more than $20 \%$, or $21.2 \mathrm{GW}$, will constitute natural gas additions. Regarding this study, we have illustrated some countries (United States, Algeria, Nigeria) which produce gas and whose percentage of electricity production from natural gas increases from time to time, after comparing these countries with the republic of the Congo from 1990 to 2015.

Figure 2 shows the percentage of electricity production from natural gas in the following countries: In the Republic of Cong, this technology started in 2003 (14.29\%) until reaching $46.66 \%$ in 2015 , i.e. growth of $32.37 \%$ United States; unlike the Congo, this technology has started since 1990 (11.92\%) until reaching $31.94 \%$ in 2015 , i.e. growth of $20.02 \%$. Algeria, the rate of use of electricity production from natural gas is very high, varying from $93.73 \%$ in 1990 to $98.36 \%$ in 2015 , i.e. a growth of $4.63 \%$, which means this is the source most used in the production of electricity. Nigeria; started in 1990 with $53.65 \%$ until reaching $81.80 \%$ in 2015 or the growth rate of $28.15 \%$. 


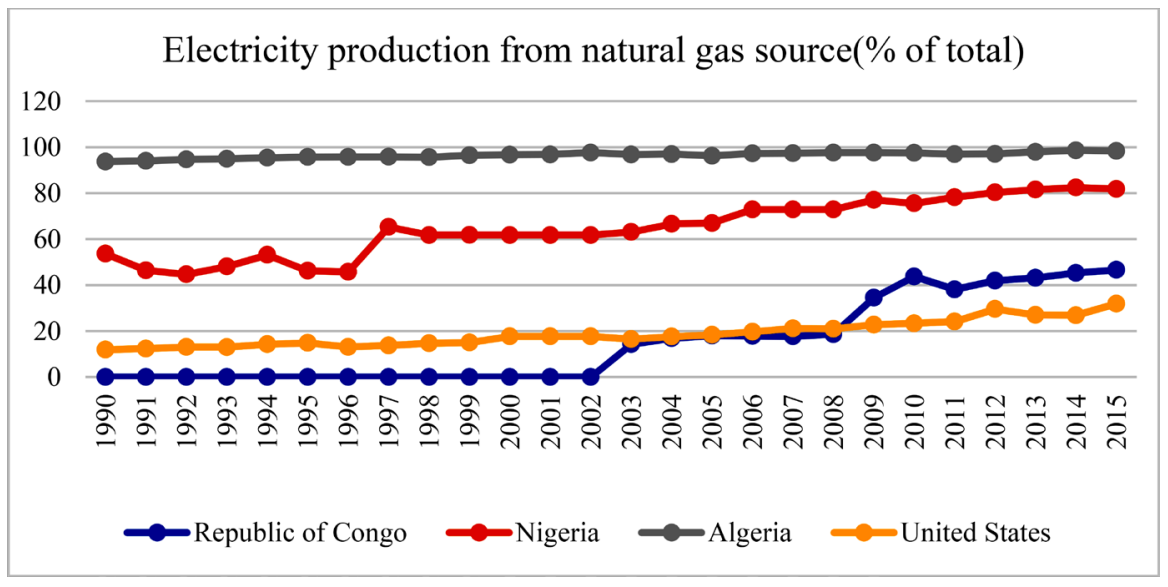

Source: Data from [35].

Figure 2. Percentage of electricity production from natural gas in Republic of Congo, Nigeria, Algeria, and the United States.

Indeed, we notice that among these four countries the republic of the Congo is the only country where this technology started with a delay of 13 years compared to other countries despite this, the rate of increase is higher (32, $37 \%)$. Consequently, it would be necessary to increase the efforts in the implementation of this technology to maintain the balance like Algeria, to reduce the use of the hydropower plant because it destroys the environment, let's enhance the national reserves to reduce the torches of gas which has effects on the atmosphere.

\section{Evolution and Prediction of Population}

The Republic of Congo is a Central African country located on the equator, sparsely populated and dense despite an honorable size. The country reached, according to estimates, 5.3 million inhabitants in 2018. And its annual demographic growth remains very high, at $+3.68 \%$ per year on average between 2010 and 2015.

Figure 3 represented the growth trends of the Congolese population from 1990 to 2017.

We carried out a study to assess the demographic growth rate in the period from 1990 to 2017, following this study we noted a growth of 2,753,965 inhabitants during this period, this requires increasing the production capacity of electricity to maintain the stability of the voltage in the distribution network.

Regarding prediction, Figure 4 represented the evolution of the population for a period going from 2021 to 2035 which has been subtracted from the statistics of the growth of the total population from 1950 to 2050 [36]; with an annual growth rate of $2.61 \%$ in 2019 .

Demographic changes and changes in subscribers will be the main determinants of electricity demand. Congo is expected to experience positive and faster growth in demand for electricity over the next decade. Congo's population growth will be one of its main challenges for the years and decades to come. 


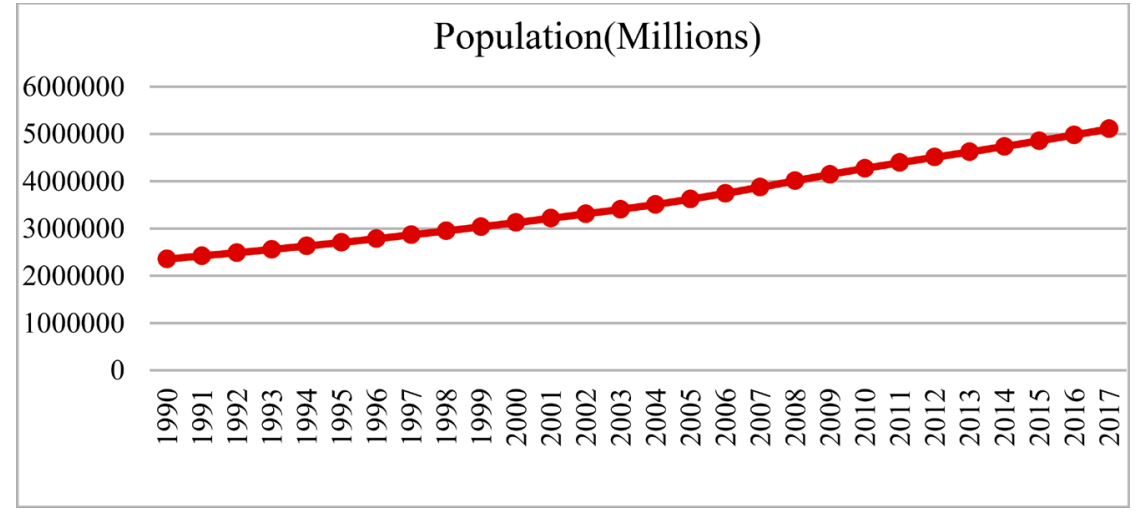

Source: Data from [36].

Figure 3. Growth trend of the Congolese population from 1990 to 2017.

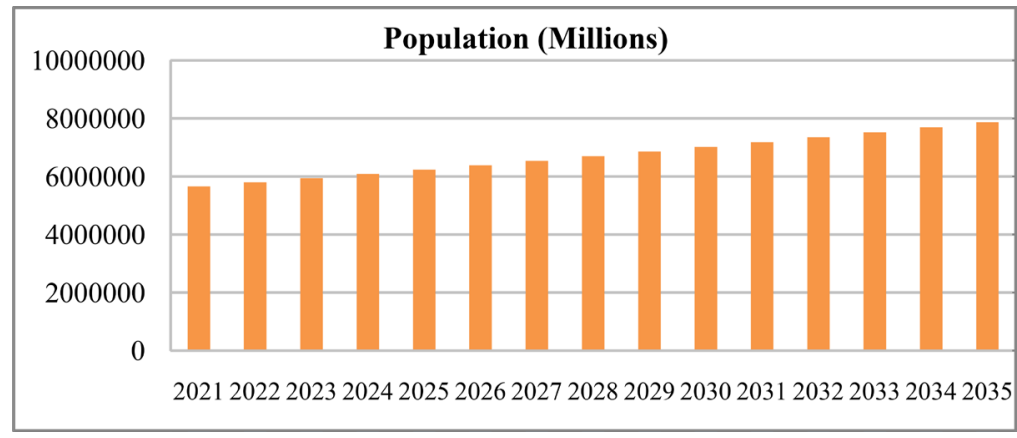

Source: Results obtained from [36] and [38].

Figure 4. Prediction of population growth rate.

\section{Electricity Production and Demand Estimation}

Recently the power generation capacity in Congo has increased due to new gas power plants, for this study we will first present the history of electricity production after demand.

We have represented the variation trends in production capacity from 1990 to 2017.

From Figure 5 we can say that the Republic of Congo has the potential of production in electrical energy for a period going from 1990 to 2017, in general, the production capacity of electricity increases with an ecard of 2.81 billion kilowatt-hours, this is explained by the growth of the population and the demand for electricity in industrial areas.

Indeed, electricity production in Congo increased from 0.49 billion kilowatt-hours in 1990 to 3.30 billion kilowatt-hours in 2017 [37], with an average annual growth of $14.62 \%$. We used the formula [38] to predict the production of electricity generation from 2021 until 2035.

Total growth rate $=($ final value - initial value $) /$ initial value

The graph below shows a sharp increase in the demand for electricity from 5.69 billion kilowatt-hours in 2021 to 38.48 billion kilowatt-hours in 2035 (See Figure 6). 


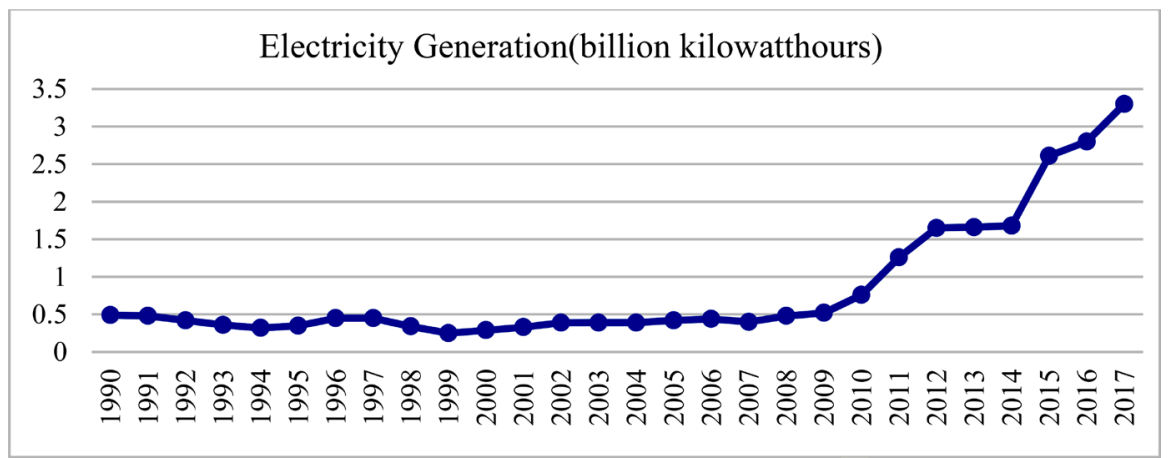

Source: Data from [37].

Figure 5. Illustration of electric energy produced.

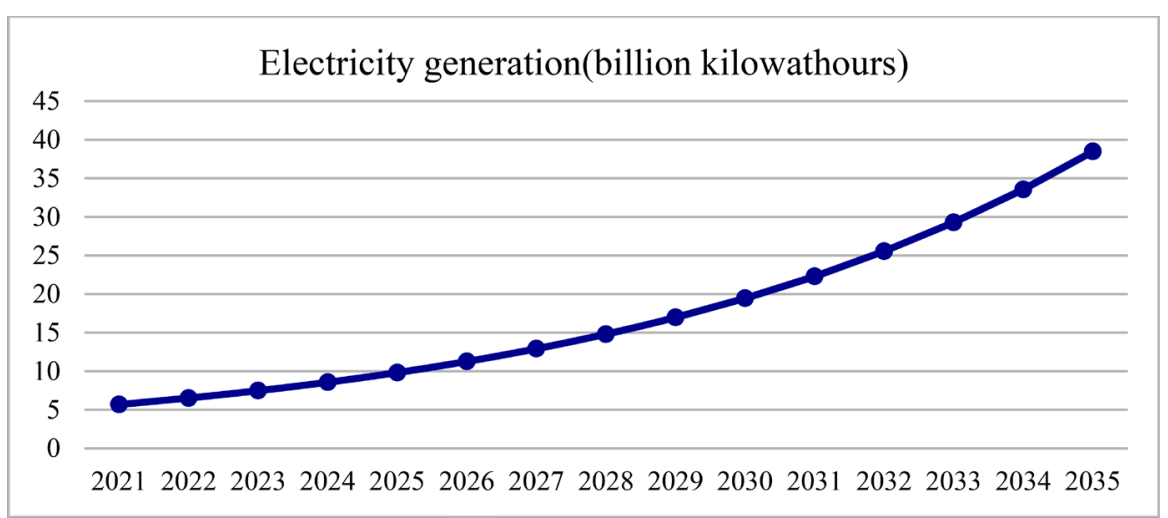

Source: Results obtained from [37] and [38].

Figure 6. Prediction of electric energy demand.

\section{Application of Gas to Wire Technology (GTW) from Congo Natural Gas Reserves}

Figure 7 illustrates the general situation, from natural gas extraction to recovery (production of electricity). Farm 1 whose tank is in Oil + gas form (associated gas) and Farm 2 whose tank is in gas form (no-associated gas): The first case, the crude (oil + gas) through the pipelinel arrives at the separator, at the outlet, there is oil which is transferred to (oil stock) and gas directed to the filter then used by the grouping of turbines G1, G2, G3, G4 and G5 which are in parallel and generate a load of $750 \mathrm{MW} /$ day or $273.750 \mathrm{MW} /$ year.

In the second case, the gas not associated through pipeline 2 arrives at the separator, leaving the natural gas arrives at the filter then used by the grouping of turbines G1, G2, G3, G4, and G5 which are in parallel and generate a load of 750 $\mathrm{MW} /$ day or $273.750 \mathrm{MW} /$ year.

Apart from that, there are also volumes of gas from operations 1 and 2 which are transferred through the pipeline 3 and 4 subsequently used for the application of other technologies.

\subsection{Evaluation of GTW Technology}

The economic evaluation was made using GTW technology for the production 


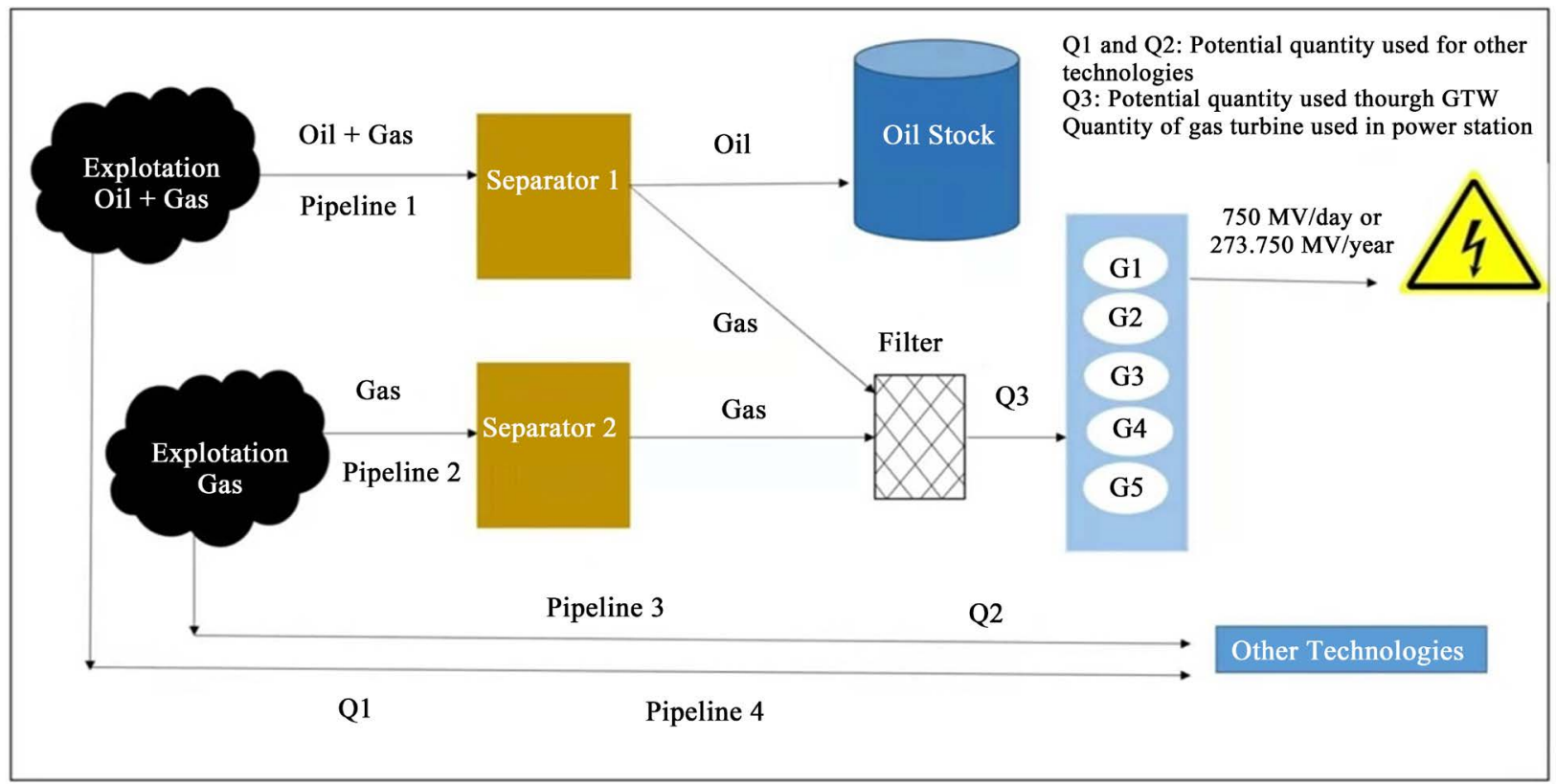

Figure 7. Representation of the gas exploitation system.

Table 1. Primary performance parameters for GT13E2 [39].

\begin{tabular}{cc}
\hline Fuel & Naturel Gas \\
Frequency & $50 \mathrm{~Hz}$ \\
Gross electricity production & $150 \mathrm{MW}$ \\
Goss Electricity Efficiency & $36.4 \%$ \\
Thermal efficiency & $36 \%$ \\
Turbine Speed & $3000 \mathrm{rpm}$ \\
Fuel Gas Temperature & $31^{\circ} \mathrm{C}$ \\
\hline
\end{tabular}

of electricity using the ALSTOM GT13E2 turbine, the performance parameters of which are shown in Table 1.

An ALSTOM GT13E2 unit consumes a total of 0.93 million cubic meters $(\mathrm{mcm})$ of gas per day and generates $150 \mathrm{MW}$ of electricity [33]. Following this, we will make an economic estimate using GTW technology for the production of electricity as part of the contribution of the gas valorization policy. According to Table 1, it will be possible that 1.69 billion cubic meters (BCM) of gas could be used to produce $273.750 \mathrm{MW}$ of electricity per year, using 5 units of turbines. Compared to Congo's natural gas reserves are estimated at 90 billion $\mathrm{m}^{3}$ [1], there will be no problem with the gas supply.

Table 2 highlights that the major capital investment goes into the acquisition of equipment such as turbines, spare parts, as well as the costs of inflation. The total capital investment estimate is 192,305,137 euros.

Figure 8 shows a plot of gas turbine units against electricity produced. For example, 5 units of gas turbines generate 750 and $273.750 \mathrm{MW}$ of gas daily and yearly respectively. 
Table 2. Estimate of gas consumption and electricity production in Congo using GTW.

\begin{tabular}{ccccc}
\hline $\begin{array}{c}\text { No. of Gas Turbine } \\
\text { (150 MW } \\
\text { Capacity/Turbine) }\end{array}$ & $\begin{array}{c}\text { Daily Gas } \\
\text { Usage }\left(\mathbf{m}^{3}\right)\end{array}$ & $\begin{array}{c}\text { Daily } \\
\text { Electricity } \\
\text { Gen. (MW) }\end{array}$ & $\begin{array}{c}\text { Yearly Gas Usage } \\
\left(\mathbf{m}^{3}\right)\end{array}$ & $\begin{array}{c}\text { Yearly Electricity } \\
\text { Gen. (MW) }\end{array}$ \\
\hline 1 & 930,000 & 150 & $339,450,000$ & 54,750 \\
2 & $1,860,000$ & 300 & $678,900,000$ & 109,500 \\
3 & $2,790,000$ & 450 & $1,018,350,000$ & 164,250 \\
4 & $3,720,000$ & 600 & $1,357,800,000$ & 219,000 \\
5 & $4,650,000$ & 750 & $1,697,250,000$ & 273,750 \\
\hline
\end{tabular}

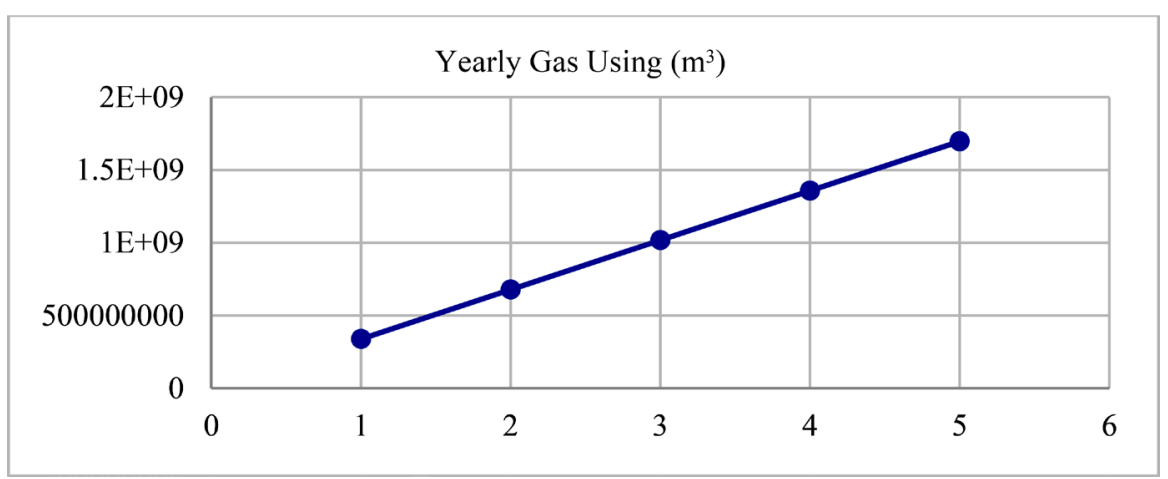

Figure 8. Graph showing units of gas turbine used versus the volume of gas produce.

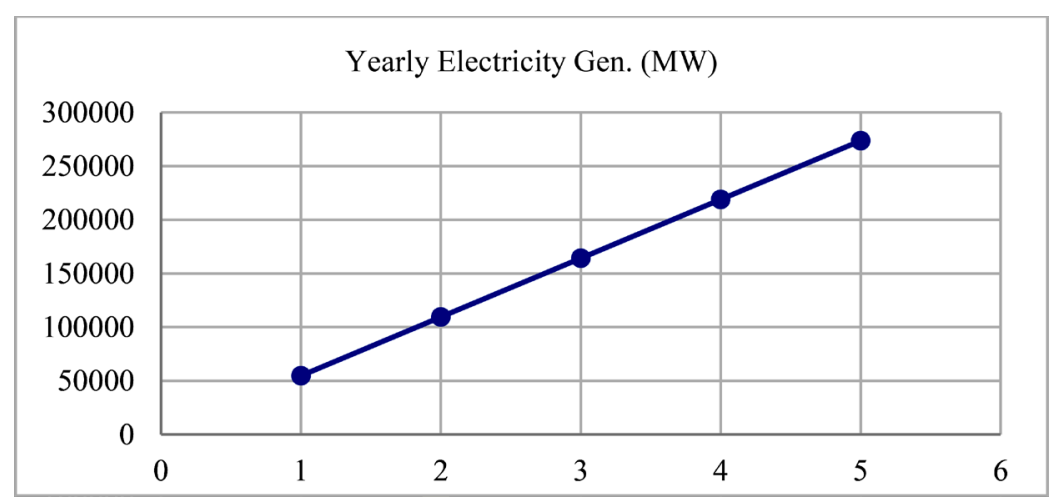

Figure 9. The graph shows gas turbine units and the number of MW used for electricity production.

Figure 9 was used to describe the effect of the number of gas turbines and the production of electricity respectively. In this study, we used gas turbine ALSTOM GT-13E2 with a capacity of $150 \mathrm{MW}$. It clearly shows a proportional increase in the gas used with an increase in the number of gas turbines.

Energy consumed: 365 days $\times 24 \times 750,000 \mathrm{kw}=6.57 \times 10^{9} \mathrm{kWh}=6.57$ billion kilowatt-hours/year.

Table 3 was estimated by the data collected [40] and demonstrates the economic implications through the GTW technology used by the SNPC in the Republic of Congo, using the factors indicated previously such as the turbine units, the amount of energy generated and the volume of gas used. 
Table 3. Estimate of investment capital according to the data collected.

\begin{tabular}{cc}
\hline Description & Cost in $€$ \\
\hline Equipment (5 Units of Gas Turbine) & $1,123,075,357.9$ \\
Installations of equipment and Piping & $42,239,399.6$ \\
Maintenance/Working Cost & $26,990,379.5 /$ year \\
Total investment capital & $192,305,137$ \\
\hline
\end{tabular}

\subsection{Estimation of Electricity and Financial Production}

The estimate is based on the assumption that the availability and consistency of gas turbines are 100\% throughout the year (365 days a year). We also assumed that the units of the 5 turbines operate at full power, $150 \mathrm{MW} \times 5$ units, and sell all the electricity produced to the national grid. Product cost for the plant, total annual income, gross profit, net profit, and rate of return (ROR) calculations were estimated by the following equations [41].

1) Product cost for sale $\times$ B.E.P $=$ Product cost for Plant $\times$ B.E.P capacity + Fixed Charge

$$
\begin{gathered}
P \times Q=C_{I}+V C \times Q \\
Q=F C /(P-V C)
\end{gathered}
$$

2) Product cost for plant $=$ Direct Production Cost $\div$ Plant Capacity;

3) Yearly Income in B.E.P capacity, $C=$ Break-even point capacity $\times$ product cost for sale

$$
C=Q \times P
$$

4) Total Yearly Income, $S$ in $(€ / y r)=$ Capacity of Unit per year $\times$ Product Cost for sale;

$$
S=P \times Q
$$

5) Gross Profit, $R$ in $(€ / y r)=$ Total yearly income - Yearly income in B.E.P capacity

$$
R=S-C
$$

6) Net Profit, $N=0.7 \times R$;

7) $R O R=$ Annual Profit/Capital Investment $\times 100$

$$
R O R=N / T C I \times 100
$$

The cost of the product for sale is the retail price of electricity per kWh. The total cost of the product for sale is the financial value of all the electricity produced, which is also the total annual income.

The cost of the product for power plants is the cost of producing electricity per kWh.

Considering the decree: $2017-248$ of July 17, 2017, fixing the conditions for the exercise of independent production of electricity (section 3 data collection), we suggest that the National Company of Petroleum of Congo (SNPC) invest in the realization of this project and the electricity produced will be sold by 
Table 4. Estimated income and return costs.

\begin{tabular}{cc}
\hline Caption & Value $(€)$ \\
\hline Cost of sale of electricity & $0.06 / \mathrm{kWh}$ \\
The capacity of turbine Per Year & $273 ., 750,000 \mathrm{kWh}$ \\
The total cost of electricity sale/year & $16,425,000$ \\
Product cost for turbine operation & $0.006 / \mathrm{kWh}$ \\
Direct production cost & $1,642,500$ \\
Fixed charges & $2,463,750 / \mathrm{year}$ \\
Break-even point capacity & $45,625,000 \mathrm{kWh}$ \\
Yearly income in B.E.P capacity & $2,737,500$ \\
Total yearly income & $16,425,000$ \\
Gross profit & $13,687,500$ \\
Net profit & $9,581,250$ \\
ROR & $4.98 \%$ \\
\hline
\end{tabular}

Electrical Energy of Congo $\left(\mathrm{E}^{2} \mathrm{C}\right)$.

The residential sales tariff system currently in use is around 0.06 euro/kWh [34]. Therefore, it was used as the basis for calculating income from electricity sales and generate income. On this basis, the calculation is provided to demonstrate the financial output of a turbine unit with a power of $150 \mathrm{MW}$ each.

The estimate has shown that GTW technology is one of the cost-effective means of upgrading gas. This is linked to the statement of revenues and return costs in Table 4 which shows an annual net profit of 9,581,250 euros with a return on investment of $4.98 \%$ per year. This initiative has a positive advantage for a long-term investment since the recovery of the latter should be around 20 years.

\section{Conclusion and Recommendation}

The main objective of this study is to apply the gas to wire technology (GTW) from gas reserves in order to contribute to the gas valuation policy.

The results show that investment capital of 192,305,137 euros was required with a net profit of 9,581,250 euros at an annual rate of return of $4.98 \%$ for an investment payback period of approximately 20 years. This project will turn the national oil company of Congo into an oil company that upgrades gas and produces electricity.

Given that gas utilization depends on gas production, there is a urge need to improve gas production capacity in the Republic of Congo, while reducing the volumes of gas flared. To do so, we suggest the following recommendations to the Congolese government:

1) Strengthen the existing legal framework, more particularly the Hydrocarbons Code ( $\mathrm{n}^{\circ}$ 2016-28), section 2-associated gas flaring: Articles 136 and 137 deal with the modalities and authorizations of gas flares in the oil industries [2]; 
2) Creation of a subsidiary which deals only with gas valorization (production of electricity through natural gas) within the national petroleum company of Congo (SNPC);

3) Put in place fiscal/tariff policies to encourage oil operators to take an interest in gas exploitation, facilitate new investors in the gas sector.

\section{Acknowledgements}

The authors are thankful to the Pr. Zhang Xing Ping as a supervisor for providing necessary assistance.

\section{Conflicts of Interest}

The authors declare no conflicts of interest regarding the publication of this paper.

\section{References}

[1] IndexMundi Data (2019) Africa Reserves of Natural Gas. https://www.indexmundi.com/map/?v=98\&r=af\&l=en

[2] Ministry of Hydrocarbons of the Republic of Congo (2019).

[3] Abas, N., Kalair, A., Khan, N. and Kalair, A.R. (2017) Review of GHG Emissions in Pakistan Compared to SAARC Countries. Renewable and Sustainable Energy Reviews, 80, 990-1016. https://doi.org/10.1016/j.rser.2017.04.022

[4] Rahimpour, M.R., Jamshidnejad, Z., Jokar, S.M., Karimi, G., Ghorbani, A. and Mohammadi, A.H. (2012) A Comparative Study of Three Methods for Flare Gas Recovery of Asalooye Gas Refinery. Journal of Natural Gas Science and Engineering, 4, 17-28. https://doi.org/10.1016/j.jngse.2011.10.001

[5] Meetham, G.W. (2012) The Development of Gas Turbine Materials. Springer Science \& Business Media, Berlin.

[6] Li, Z.Q., Qi, J.G. and Wu, G.S. (2008) From 3R to 5R: Reconstruction of the Basic Principles of Modern Circular Economy. Research on Quantitative Economy, Technology and Economy, 48, 53-59.

[7] Wu, P. and Shan, B.G. (2009) Experience and Enlightenment of Foreign Energy Conservation. State Grid, 7, 50-51.

[8] Zhang, W.B., Pan, Y.C., Cui, Z.Q., et al. (2012) Existing Problems and Countermeasures for Natural Gas Power Generation in China. Energy Technology Econo$m y, 24,15-17$.

[9] Fan, X.L. and Zhang, H.J. (2007) Development Trend of China's Natural Gas Industry. Eco-Economics, 22, 94-98.

[10] China Gas Network (2012) Development Trend of China's Natural Gas Industry.

[11] Kang, C.Q., Zhou, T.R. and Chen, Q.X. (2010) Challenges and Countermeasures of Power Enterprises in Low Carbon Economy. Source Technology and Economy, 22, $1-8$.

[12] Yao, K. (2007) Discussion on Environmental Protection Discounts for Coal-Fired Power Stations. Tianjin Electric Power Technology, 11, 8-10.

[13] Zhao, K. (2012) Natural Gas Power Generation Should Be Given a Moderate Priority. 
[14] Hu, W.P. (2011) Comparative Study on the Benefits of Main Energy Power Generation in China. North China Electric Power University, Baoding.

[15] Yang, W.R. (2007) South Research on Natural Gas Power Generation in Regional Power Market. North China Electric Power University, Beijing.

[16] Wang, D.Q. (2002) Some Suggestions for China Petroleum to Develop Natural Gas Power Generation Market. International Petroleum Economy, 24, 34-37.

[17] Shan, W.G. (2011) Development and Trend of Global Natural Gas Market. China Energy, 33, 13-16.

[18] Luo, L.Z. (2008) Research on China's Natural Gas Pricing Issues. Price Theory and Practice, 27, 25-27.

[19] Gao, J. and Dong, X.C. (2009) Research on the Integration Reform of China's Natural Gas Price System. Price Theory and Practice, 29, 13-16.

[20] Mei, T. and Ding, J. (2010) Thoughts on Deepening Natural Gas Price Reform. Price Theory and Practice, 30, 62-63.

[21] Du, D.Y. and Huang, H. (2013) Experience and Enlightenment of Natural Gas Power Generation in Foreign Countries. Shanghai Gas, 34, 23-26.

[22] Cai, Y. (2010) Preliminary Exploration of Electricity Price Reform of West Second Line Natural Gas Power Generation in Shenzhen City. Gas Technology, 17, 4-7.

[23] He, C.Q. and Chen, Z.Q. (2000) Prospect Analysis of Natural Gas Power Generation in East China Power Grid. East China Power Li, 33, 3-4.

[24] Jiang, P.F. (2013) Analysis of the Necessity and Economics of Developing Natural Gas Power Generation in the Pearl River Delta. Energy and Economy Yes, 13, 23-25.

[25] Dong, J. and Zhang, J. (2009) Research on the Policy of Natural Gas Power Generation in the Second Line of West-East Gas Pipeline. China Mining Industry, 18, 74-78.

[26] Hua, H. (2011) Suggestions on Classification and Examination and Approval Methods of Natural Gas Power Generation Projects. Journal of Shenyang Institute of Technology (Natural Science Edition), 7, 289-297.

[27] EI-Khattam, W. and Salama, M.M.A. (2004) Distributed Generation Technologies, Definitions and Benefits. Electric Power Systems Research, 71, 119-128.

https://doi.org/10.1016/j.epsr.2004.01.006

[28] Pepermans, G., Driesen, J., Haeseldonckx, D., et al. (2005) Distributed Generation: Definition, Benefits and Issues. Energy Policy, 33, 787-798.

https://doi.org/10.1016/j.enpol.2003.10.004

[29] World Survey of Decentralized Energy (2011) World Alliance of Decentralized Energy (WADE). 1-46.

[30] Diaz-Rainey, I. and Ashton, J.K. (2008) Stuck between a ROC and a Hard Place, Barriers to the Take-Up of Green Energy in the UK. Energy Policy, 2, 3043-3051. https://doi.org/10.1016/j.enpol.2008.03.038

[31] Zeng, M., Tian, K., Li, N., et al. (2010) Economic Benefit Analysis and Evaluation Model of Distributed Generation. Power System Technology, 34, 129-133.

[32] $\mathrm{Hu}, \mathrm{Y} ., \mathrm{Xu}, \mathrm{C} ., \mathrm{Wu}, \mathrm{Y} .$, et al. (2008) Analysis of Economic Factors Affecting User-Side Distributed Power Generation. Electric Power Automation Equipment, 28, 29-33.

[33] Ojijiagwo, E., Oduoza, C.F. and Emekwuru, N. (2018) Technological and Economic Evaluation of Conversion of Potential Flare Gas to Electricity in Nigeria. 28th In- 
ternational Conference on Flexible Automation and Intelligent Manufacturing (FAIM2018), Columbus, 11-14 June 2018, 444-451.

https://doi.org/10.1016/j.promfg.2018.10.068

[34] World Bank, GGFR (2016) Methodology and Netback Results. Mott MacDonald Analysis, 60.

[35] Electricity Production from Natural Gas Sources. https://knoema.fr/WBCC2020/world-bank-climate-change?tsId=1110850

[36] Population Total Evolution of Republic of Congo. https://knoema.fr/search?query=population $\% 20$ total\%20evolution $\% 20 \mathrm{of} \% 20 \mathrm{rep} . \mathrm{of}$ \%20congo

[37] Electricity Generation. https://knoema.fr/atlas/Congo/topics/Énergie/Électricité/Electricity-net-generation

[38] Growth Rate Formula. http://lemercier.ouvaton.org/docannexe.php?id=113

[39] ALSTOM Power (2010) Plant Data Sheet for ALSTOM Gas Turbine GT13E2 within Open Cycle Plant in Port Harcourt, Nigeria. Part of Documentation from Case Study.

[40] Ojijiagwo, E., Oduoza, C.F. and Emekwuru, N. (2016) Economics of Gas to Wire Technology Applied in Gas Flare Management. Engineering Science and Technology, an International Journal, 19, 2109-2118. https://doi.org/10.1016/j.jestch.2016.09.012

[41] Peters, M.S. and Timmerhaus, K.D. (1991) Plant Design and Economics for Chemical Engineers. International Edition, McGraw-Hill, New York. 